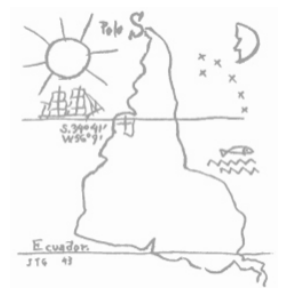

ALTERNAUTAS

Héctor Alimonda

\title{
In the key of south: Latin American political ecology and critical thinking
}

Alternautas is a peer reviewed academic journal that publishes content related to Latin American Critical Development Thinking.

It intends to serve as a platform for testing, circulating, and debating new ideas and reflections on these topics, expanding beyond the geographical, cultural and linguistic boundaries of Latin America - Abya Yala. We hope to contribute to connecting ideas, and to provide a space for intellectual exchange and discussion for a nascent academic community of scholars, devoted to counter-balancing mainstream understandings of development.

How to cite:

Alimonda, H. (2019), In the key of south: Latin American political ecology and critical thinking, Alternautas, 6(1), 84-101. URL :

http://www.alternautas.net/blog/2019/5/14/in-the-key-of-south-latinamerican-political-ecology-and-critical-thinking

Editor : Alternautas

http://www.alternautas.net

London, UK.

ISSN - 2057-4924 
In the Key of South $\mid 84$

HÉCTOR ALIMONDA ${ }^{1}$

\section{In the key of south: Latin American political ecology and critical thinking ${ }^{2}$}

Here I attempt to think about the insertion of a recent theoretical-political field and diverse and branching development — that of Latin American Political Ecology—into a plural framework with very specific characteristics—the tradition of Latin American critical thinking. A first version of this obsession was recently published (Alimonda, 2015).

Perhaps it would be redundant to clarify that I do not intend to sketch an itinerary in the open field of formal history of ideas in Latin America, among what has been thought and written in this corner of the world. Instead, I attempt to identify Latin American ideas as a critical, perhaps one could say ontological, reflection about its own existence. We will be delimiting diffuse pathways in a very steep and foggy territory, full of spectres, among which the new passengers will choose their ancestors or kill the dead, as Derrida said (1994: 119). ${ }^{3}$

\footnotetext{
'Translated by Emilie Dupuits and Alexander D'aloia.

2 Translated from the original: Alimonda Héctor, "En Clave de Sur: la Ecología Política Latinoamericana y el Pensamiento Crítico", En Alimonda Héctor, Toro Pérez Catalina y Martin Facundo, Ecología Política Latinoamericana, 2017, CLACSO.

This article was originally published in: http://www.alternautas.net/blog/2019/5/14/in-the-key-ofsouth-latin-american-political-ecology-and-critical-thinking on May $14^{\text {th }}, 2019$.

${ }^{3}$ We are talking about inheritance, legacies and, following Derrida, it is worth remembering that, according to him, "An inheritance is never gathered together, it is never one with itself. Its presumed unity, if there is one, can consist only in injunction to reaffirm by choosing. "One must" means one must filter, sift, criticize, one must sort out several different possibilities that inhabit the same injunction. If the readability of a legacy were given, natural, transparent, univocal, if it did not call for and at the same time defy interpretation, we would never have anything to inherit from it. We would be affected by its cause-natural or genetic. One always inherits from a secretwhich says "read me, will you ever be able to do so?" (33).
} 


\section{Latin American Critical Thinking in The Key of South}

On several occasions I had the chance to hear Professor Anibal Quijano opening his classes and conferences by resorting to a performative provocation, the question regarding our continent's name, no doubt as a resource to deconstruct the listeners' certainties. Indeed, whatever the usual names (Latin America, imposed by the French colonial project in Mexico, 'Indoamerica' of Haya de la Torre, Hispano or Iberoamerica), all those denominations leave aside some constituent elements of our identity. Obviously, the problem is not the names but that identity. It may be better erasing them and starting again, as it is happening with the recovery of the Kuna name 'Abya Yala'. For convenience and communicability, we will use the terms Latin America, Latinoamérica, and Latin American, but accepting the perplexity of its precise definition that refers to, from the beginning, a fundamental and problematic origin.

From his Marxism in the key of Latin America, José Arico reflected that "when we talk about Latin America, we evoke a pre-constituted reality that is not so, that is in fact a 'black hole', an open problem, an unachieved construction or, as Mariategui was pointing out for his nation but which can be extended to the continent: a project to be realised" (1988: 42).

It is a nominalist problem then, whose foundation lies in the complexity of the continent's historical heritage. However, by recognizing this relevance, where the difficulty of the words refers to the vicissitudes of a conflictive structure, as Freud would appreciate, the whole unfolds into new directions and meanings. We are in the presence of nations that have existed as such for two hundred years in the international order (they can't, therefore, be assimilated into the colonial world constituted at the end of the 19th century). ${ }^{4}$ But at the same time, they continue in the protean formation process. ${ }^{5}$ On this subject, Arico also reflected that "Latin

\footnotetext{
${ }^{4}$ Which, incidentally, excludes us from the post-colonial discussion in terms of that which is located within the ex-British Empire (Coronil, 2008; Pratt, 2008; among others).

${ }^{5}$ Obviously, it is also relevant to ask to what extent the "central countries", as they used to be called, are not also in the process of formation, in which case the South is showing the future to the North, as Comaroff and Comaroff suggest (2013).
} 
American societies are, essentially, national-popular, meaning that they still vigorously experience the problem of their national destiny, of whether or not they are nations [...] They question their identity, what they are [...] still going through a stage of Sturm und Drang — as keenly noted by Gramsci referring to our America-, [...] of a romantic access to nationality [1986]" (cited in Cortés, 2015).

Thus, the condition of the enunciation of Latin American critical thinking starts with an agonizing search for identity that leads to a continuous investigation into the origins and to an anxious interrogation of the nation building processes. Given the different interpretations of the authors who have dealt with the subject, we will consider Latin American critical thinking from a perspective that relates it to (without deriving it from, naturally) the critical theory tradition. In a suggestive work, Martin Cortes (2011) has pointed out the existing similitudes between this place of enunciation of Latin American thinking and the working program of the Frankfurt school of Critical Theory.

For Andrew Biro, “at a very general level, 'critical theory' can be defined as a knowledge aiming to reduce domination. In contrast to social science, whose model is the free, 'objective' vision of values, critical thinking starts with the normative assumption that oppression must be reduced or eradicated, and organises knowledge toward that end" (2011:3).

Boaventura de Sousa Santos also refers to the possibility of a critical theory linked to the Frankfurt school, specifically to the work of Max Horkheimer. "I understand critical theory as not reducing reality to what exists. [...] Critical analysis of what exists relies on the assumption that facts of reality do not exhaust the possibilities of existence and that, therefore, there are also alternatives able to overcome what can be critiqued in that which exists. Discomfort, indignation and non-conformity towards what exists serve as sources of inspiration to theorize about how to overcome such a state of things" (2006: 18).

The foundation of critical thinking, then, relies upon the disconformity between the existing reality and the search for alternatives, from the characterization of the present situation, whose causes can, obviously, be found in the past. This framework is at the 
core of the Latin American thinking, responding to the challenge of "thinking the nation", the creation of a knowledge that advances diagnostics and solutions, without claiming the objectivity of "normal" social sciences. Moreover, in general, these perspectives also imply a critical epistemology, that is to say a questioning of the categories and procedures of dominant scientific discourses. In the case of Latin American, there is an emphasis on denouncing the exogenous and Eurocentric nature of theoretical-methodological resources that configure established knowledge systems.

Some authors, most of all those belonging to the generation of the contemporary classics of the Latin American social sciences, explicitly consider that Latin American critical thinking is linked to their support during the height of Marxism (see Quijano, 2014; Fals Borda, 2012; Echeverria, 2011). At one extreme, the Guatemalan Edelberto Torres Rivas (2011) argues that Latin American critical thinking extends from the Cuban revolution to the fall of the Sandinista government, and now would have ceased to exist. This does not seem so to us, first of all because Marxism never covered the whole Latin American reflection, and much less covered the set of popular resistances in the region.

But, on the other hand, we should, in either case, examine that to which Marxism pertains. Our hypothesis is, precisely, that Latin American thinking always worked in an anthropophagic relationship (as advocated by the modernist Brazilian Oswald de Andrade) regarding the intellectual and aesthetic developments of the metropolitan centres. Even a highly coherent theoretical matrix, to the point of being punctilious, such as the Marxism of the period of the Third International, had to be reformulated at a grand scale in order to put down roots in Latin American lands and minds (was the Cuban revolution ever a proletarian revolution?). We will return to this point.

What we find more productive, in any case, is a perspective that, as other authors claim, traces the origins of that persistent dissatisfaction with the present situation, which gave rise to Latin American critical thinking, to the process of independence (Martins, 2006: 925). To take an example: a text such as the Carta de Jamaica, of 
1815, in which Simon Bolivar analyses with an acute critical sense the political perspectives that, in his opinion, would lie ahead for the future independent republics, quite rightly deserves to be part of the references (even of the protohistory) of Latin American critical thinking.

How to characterize, except as a critical thinking based on the terrible recognition of a problematic identity, the following reflection of Simon Bolivar: "we are not Europeans, we are not Indians, our species stands halfway between the aboriginals and the Spanish. Americans by birth and Europeans by law, we find ourselves in the conflict of disputing the titles of possession against the natives, and to remain in the country that saw us born against the invaders' opposition: in that way, our case is the most extraordinary and complicated" (Roig, 2004).

And how not to recognize the repeated and still current urgency in this call from the Argentinian generation of 1837: "Let's try as Descartes—said Esteban Echeverriato forget everything learnt in order to enter with all the energy of our strength in researching the truth. Not of the abstract truth but of the truth resulting from the facts of our history, and the full recognition of the customs and spirit of the nation" (Roig, 2004).

The situation of subordination in the international context, the structural heterogeneity of our societies, with its cultural implications, the anguish of having to choose between different heritages and paths, the distress of a modern destiny that seems unreachable, the urgency to organize nationality through authoritative means, the hostile difficulty of the natural environment to be incorporated as an effective territory of the nation, all these elements were present from the same moment of independence, and formed an irreplaceable referent in the history of the ideas of the continent. And, since then, they were the raw material from which would flourish critical thinking. 


\section{Two Examples of Anthropophagy and Resignification in Critical Thinking}

We believe that one of the characteristics of Latin American critical thinking is the reiterated character of the "rooted avant-garde" of its protagonists, as the Brazilian professor Alfredo Bosi (1992) labelled the Peruvian socialist group of José Carlos Mariategui. Avant-garde in the sense of stemming from the incorporation of perspectives that have already advanced beyond contemporaneous political and social thinking, upon which was made a significant translation process allowing its operationalization in the analysis of national realities.

We want to come back to this point in relation to Latin American political ecology. But what we are interested in, at this moment, is to refer to two cases of the resignifying incorporation of notable traditions of Western society by Latin American critical thinking, that of Marxism and the social doctrine of the Church.

Regarding Marxism, the odd figure of José Carlos Mariategui started a reconstruction of the tenets of this tradition, in the conditions of the 1920s, from its inclusion in a perspective of interpretation and political articulation consistent with Peruvian society during the time period. The recognition of the national issue and its incomplete nature; the indigenous problem as a central question of that Peruvian nationality, especially focused on the issue of land access and enabling the constitution of the indigenous peasantry as a revolutionary subject; the affirmation of the unequal and combined character of economic evolution, based on the convergence between the traditional forces of backwardness and modernity, which made him doubt about the viability of modernity and development, in the very early stages of the 20th century; the strategic importance of politico-cultural tasks-all of these elements appear in his Marxist interpretation of Peruvian society, to a large extent divergent with the central lines of the contemporaneous canonical Marxism of the Third International.

This Latin American Marxism that Mariategui put into action continued to inspire Latin American thinking for decades and is undoubtedly present in a large part of the critical production subsequent to the period. 
Another resignifying incorporation of the greatest importance relates to the social doctrine of the Catholic Church, and by extension to Christian social thinking, through the Liberation Theology (Boff, 1992) and the Philosophy of Liberation (Dussel, 2008). Realizing a true inversion of its evangelizing processes, a significant part of the Latin American Church embraced its commitment to the popular sectors as the core of its pastoral activity. At the same time, theologians and philosophers proposed profound reconversions of the doctrinal orientations in new translations and elaborations now having as a basis the Church's roots alongside the poor and in Latin American soil.

In 2015, the Encyclical Laudato Si, by Pope Francisco, recovering the inspiration of fraternity with nature of San Francisco de Asis, and incorporating at the same time the Latin American reflection on Political Ecology, formed a particularly transcendental document linked to the long and effective tradition of Latin American critical thinking (Francisco, 2015).

In that regard, Antonio Elizalde says that "the detailed reading of the analysed documents allows me to state that: a) in the Encyclical Laudato Si' of Pope Francisco, a large part, if not all, of the reflections made in Latin America on sustainability and social justice issues are included; b) its argument is a call toward a profound change in the civilizing processes; $c$ ) its apparently catastrophic tone nonetheless expresses a profound hope in the possibility to turn the tide and outline the main ways to do so; d) it recovers the figure of Francisco de Asis and uses it to mark the path that the main institution on the planet - the Catholic Church — should follow; e) with an unambiguous language critiques the real powers (economic and political) that today govern the world, and the behaviours, beliefs and attitudes of those who exercise them; f) it proposes an ecological conversion towards sobriety, humility, fraternity, a new universal solidarity and a culture of care; and g) it calls for the spread of a new paradigm regarding human beings, society and relations with nature" (Antonio Elizalde, 2015: 145-146). 


\section{The Latin American Political Ecology}

Over the past two decades, the so-called political ecology has spread through the international intellectual field, especially in Latin America. Essentially originating from academic developments from the Anglo-Saxon (such as the human ecology studies, the geography of Carl Sauer and the urban cultural studies of Lewis Munford) and French (a solid geographic and anthropologic production, combined with a tradition of regional economy) traditions, it does not, however, register major reference works that establish new paradigms or points of departure. Political ecology was established in a molecular way from the emergence of new theoretical and practical questions and challenges for which there were no answers at hand. On the one hand, an eco-political turn emerged in different disciplinary areas, opening a twofold working program: the rereading of the disciplinary tradition itself, from new angles, and the establishment of new interdisciplinary dialogues. At the same time, a long-term perspective can verify that this eco-political turn was also a response (or, at least, an intellectual transformation aiming to formulate answers, without giving this circumstance a necessary determination) to the presence of new socio-political subjects who, in such advanced societies, assumed critical and active positions in relation to crucial issues such as pacifism in times of the Cold War, critiques of consumerism, nuclear energy policies and the protection of natural environments, often linked to the emergence of "green" parties. There were theorists external to academia, such as André Gorz, who tried to reformulate the anti-capitalist critical tradition in order to highlight the new challenges. ${ }^{6}$ In the last decades of the 20th century, it also became evident that a new dimension in the capital/nature relationship was emerging, consolidating mechanisms of appropriation and exploitation of planetary resources of unknown dimensions and effects until then. ${ }^{7}$

\footnotetext{
${ }^{6}$ André Gorz explicitly used the term political ecology. For Gorz, defending the planet's ecology could be captured by the oppressive logic of capitalism, with an eco-fascist physiognomy. This is why ecology should be political, implying the inclusion of a critique of the forms of appropriation and exploitation of nature and human beings by industrialism, which not only controls production and work, but also imposes consumption models and the formation of subjectivities.
}

${ }^{7}$ An excellent review of the intellectual origins of political ecology is available in Leff (2015). 
It was from this time that the term 'political ecology' started to circulate throughout Latin America. At the present time, various authors who have assessed this intellectual field agree in characterizing Latin American Political Ecology as a specific politicalintellectual tradition, with a dynamic structure of development that has no equivalent in other political-intellectual areas of elaboration (Martinez-Alier, 2014; Martin and Larsimont, 2014; Delgado Ramos, 2013; Bryant et al., 2012).

When he received the title of doctor honoris causa at the National University of Cordoba, Joan Martinez-Alier (2014) said that "Political ecology analyses socioenvironmental conflicts. At the same time, the term designates a broad social and political movement for environmental justice that is stronger in Latin America than in other continents. This movement fights against environmental injustices at the local, national, regional and global scales [...] In Latin America, political ecology is not so much a university specialization within human geography or social anthropology departments (in the style of Michael Watts, Raymond Bryant, Paul Robbins), as its own field of thought of international relevance with authors very attached to environmental activism in their own countries or on the whole continent".

Another example is the presentation by Martin and Larsimont. After identifying the existence of three trends in the international field of political ecology, and referring to the first two as Anglo-Saxon political ecology and French political ecology, they deal with the third one, Latin American Political Ecology: "Although one could identify in the Latin American Political Ecology influences and elements of a more or less disciplinary and academic origin, without a doubt its defining characteristics relate to an encounter between the Latin American tradition of critical thinking and the vast peoples' experiences and strategies of resistance in the face of pillaging and the "economy of robbery". We will mention the distinguished early contributions of José Carlos Mariategui, Josué de Castro, Eduardo Galeano, among many others. However, since the end of the 90s, a differentiated perspective for dealing with society-nature relationships in the region has emerged. The difference of this perspective is probably its aspiration to do so from a Latin American "place of enunciation". This implies recognizing the theoretical and territorial spheres existing 
outside the great consolidated traditions of Western geopolitical thinking. Additionally, this place, according to the ones who converge in the Modernity/Coloniality (M/C) Research Program, ${ }^{8}$ stands in an ethical, political and epistemological position crossed by the modern/colonial experience but, at the same time, aims to create conditions for decolonization. The central argument is that the Latin American 'mark of origin' is founded on the catastrophic trauma of the conquest and integration in a subordinate and colonial position in the international system. This means, therefore, that Latin American Political Ecology gives a relevant place to the historical experience that European colonization implicated as a rupture with the origin of the particular heterogeneity and ambiguity of Latin American societies (Alimonda, 2005). This, in turn, supposes the construction of an environmental history of the region or, in other worlds, a "Siamese twin" of political ecology (Alimonda, 2005). ${ }^{9}$ Thus, Latin American Political Ecology is a collective construction in which, not without tensions and debates, diverse Latin American authors have converged, placing emphasis on the study of power relations, which are historically shaped, as mediators of society/nature relations" (Martin and Larsimont, 2014).

\section{Political Ecology and Critical Thinking}

This section includes elements we want to present here, by examining more attentively the proposal to consider Latin American Political Ecology as forming part of the critical thinking tradition of the region. We will do it in the form of a very general and necessarily limited exposition, scarcely an attempt to mark the epistemological-territorial milestones of these traditions, in the form of a glimpse of

\footnotetext{
${ }^{8}$ The M/C Program is a contemporary space of collective dialogue in and on Latin America where various well-known intellectuals participate such as Arturo Escobar, Enrique Dussel, Anibal Quijano, Walter Mignolo and Ramon Gosfogual, among others.

${ }^{9}$ Guillermo Castro Herrera has particularly contributed to the consolidation of the environmental history of Latin American and putting it in dialogue with political ecology. It is clearly relevant to question of what consists 'Latin' in Latin American Political Ecology, as German Palacio (2012) does in relation to environmental history, above all when the importance of indigenous inheritances is valued. But we accept for now the established conventions.
} 
a cognitive cartography (Jameson, 2002), and having as a methodological premise the "geopolitics of knowledge", as indicated by the title of an article by Arturo Escobar (2005), "Culture inhabits places".

It is true that our era (end of the 20th century, first years of the 21 st century) presents unique characteristics, especially regarding the relevance acquired by the violent appropriations of nature by more concentrated capital, the emergence of the global climate crisis, the regression this process implies in terms of development policies and human rights, etc. It is also obvious that the more conventional traditions of international social sciences were not prepared for the analytical response to these new challenges, which suppose a radicalization of the destructive trends of modernity, from which this social thinking is, by different ways, tributary.

For this reason, it is common to find the opinion that political ecology (and also, consequently, environmental history) would appear to be a new analytical construction, brought about by characteristics of the new global crisis and the silences of social theory and conventional politics. It is perfectly legitimate to agree with this position.

However, I would like to invert in some way the terms of the debate, not to oppose to this position, healthily iconoclastic, but at least to ensure more density in the current critical position. Throughout time, the different intellectual and political generations that emerge as critical positions reasonably argue that their time is unique and challenging, and that they face substantial problems that differentiate them from previous generations. But I think these positions are reinforced when, in the perspective of the geopolitics of knowledge, they recognize that they are rooted (reworked from new readings, of course) in strong traditions of the historicalterritorial scope itself.

From a personal point of view, then, but which refers in part to the path travelled and to my present intellectual references, I believe that the plural and collective "place of enunciation" that emerged (and is emerging) from the Latin American Political Ecology precisely relates to the characterization made by the distinguished Brazilian 
intellectual Alfredo Bosi (1992) in relation to José Carlos Mariategui and his colleagues in his intellectual and political generation: "the rooted avant-garde". ${ }^{10}$

In that sense, I would like to think about that political ecology as an avant-garde political-intellectual development, anxiously trying to respond to the tremendous challenges that this period presents for the people of our continent, recognizing the inevitable need to criticize the civilizing assumptions of conventional modernity and development. To do so, it is necessary to use all possible resources, most of all going through the paradigmatic task of updating its repertoires of action and thought, at the same time as it must try to recover the plurality of popular and critical heritages that preceded it.

Avant-garde, but rooted in the determinations of its time and the geopolitical particularities (we could say) of its points of view. A rooted avant-garde as were the generation of the University Reform and José Carlos Mariategui, or the best of the Brazilian modernists. As Latin American critical thinking was in its best moments.

I ask the permission to make reference to my personal experience. When I assumed the coordination of the CLACSO Political Ecology Working Group, in 2000, it seemed to me that a part of the task ahead was to try and establish an interweaving, in the worst case connecting intellectuals from different countries of the region who did not know each other and in the best case to trying to build a community of enunciation. But there was also another task, which in turn had two necessary and complementary aspects in the same strategic perspective: the strengthening of our proposal for the creation of a possible space of dialogue with past traditions of political and social thought.

10 Of course we agree with Ramon Grosfoguel when, taking the Zapatista movement as a reference, he defends the intellectual work thought of as a "rearguard movement", the Andar preguntando (2007: 76-77). The same idea was expressed latter on by Boaventura de Sousa Santos (2010: 40-41). 
On the one hand, as a critical social science project, it was necessary to settle accounts with the past of those disciplines. The main target, in that case, seemed to be Marxism, as the most established and institutionalized critical tradition in social sciences, but always keeping in mind that this "international" Marxism (which came from an intense process of refounding/updating from the 70s) did not exhaust the plurality of anticapitalistic critics nor even was, in the Latin American conditions, always anticapitalistic. ${ }^{11}$ It was therefore necessary to subject it to a profound critical reading, which allowed for the recovery of dimensions able to nourish our reflection (not necessarily from central or consolidated places in the tradition) and get rid of the rest, the "idols", that in the best of hypotheses only served to strengthen our indolent reason, not just to give us old answers but to discourage the actual possibility of formulating new questions.

At the same time, the example of the eco-political interpretation of José Marti developed by Guillermo Castro Herrera and the discovery of a Brazilian eco-political thinking tradition from the 18th century, presented by José Augusto Padua, showed me that we also had a decisive task in relation to the origins and identities of Latin American thinking. Our critique would come to be more powerful precisely if it could be rooted in a tradition and if we could recognize ourselves (as in the blood group or the physiognomy of our ancestors) in the genealogy of Latin American critical thinking. Hence, I propose to think about the constitution of the place of enunciation of Latin American Political Ecology in continuity with this thinking.

In a first place, Latin American critical thinking and political ecology share the same starting point of doubt about our identity and the anxious search for the keys of the same. In that case, we only have certainties that we are not equals to the tutelary exemplifying countries of modernity and development. Neither are we equals, incidentally, to societies of other continents, where the destruction of traditional

\footnotetext{
"As Pancho Arico said, with the sacralization of the "progressive" aspect of the development of productive forces, El Capital in Latin America was more the book of the bourgeoisie than of the proletariat. "Por isso, uma obra que era concebida por Marx como o maior golpe teórico contra a burguesia, converteu-se, nos países atrasados, no livro dos burgueses, isto é, no mais solido fundamento para a aceitação da necessidade e progressividade do capitalismo tal como se configurou concretamente na Europa ocidental" (Aricó, 1982: 62).
} 
cultures by modernizing eurocentrism did not reach the same extremes of America. In Asia and Africa, there are societies that can return to the legacies of their past, but it is more difficult in America. This distrust, of course, extends to the theoretical, conceptual and methodological instruments with which to think, as tributary tools of Eurocentric modernity.

Second, this search for identity can only find answers by resorting to an examination of our past. Hence, the use of a historical perspective of interpretation is present in the whole Latin American essay tradition, and also in political ecology, in its connection with environmental history. In doing so, the role played by the process of the Iberian conquest is evident in the definition of that identity, destroying native civilizations and incorporating us into modernity/coloniality in subordinated positions. From there, and in continuity with colonialism and the project that modernity had for us, emerged our particular structural heterogeneity, which manifest itself in economy, society, culture, memory, identities, the systematic subordination of populations excluded from citizenship, the difficulties in building a republican political regime that functioned effectively, and a Nation State capable of acting legitimately, the persistent colonial attitude also in regard to nature, our economies' orientation in direction of the world market, in cyclic cadences of euphoria and destruction, and many more other evils.

Third, by enunciating its more general points of view, both critical thinking and Latin American Political Ecology do it in reference to a common geo-historical reality, in which they mutually recognise each other, even when they deal with a particular national society. As an example, when José Carlos Mariategui wrote the Siete Ensayos de Interpretacion de la Realidad Peruana, it is clear that his critical discursivity was accompanying Peruvian evolution in the different issues of its repertoire, but also that crouching behind there is a text where his analysis questions the region's identity and history. Indeed, he explicitly uses the comparison with Argentina as an interpretative resource (even if at this point it is too optimistic). In the same way, when any Latin American reads Josué de Castro's works on hunger in Brazil, it is interpellated, at the same time, by the reality of hunger and social deprivation in its own country. The generalization of the offensive for environmental plunder and "accumulation by 
dispossession" throughout the region is such that the various books collecting case studies of environmental conflict, especially in relation to large-scale mining, present situations that appear to reproduce the same general characteristics in all countries (indeed, they often involve the same companies).

Fourth, between critical thinking and the political ecology made in Latin America, there is a shared distrust of the theoretical and methodological instruments of the conventional social sciences. Some doubts were and are exhibited regarding their relevance and applicability to the particularities of our realities; their links with the finalist historical perspectives that from the beginning placed us as "deviant cases" in the march for progress; and their difficulty, being elaborated from the repertoires of modernity, in questioning our populations from positions of respect and autonomy. For this reason, the methodological tools of critical thinking and political ecology often present a prominent anti-positivist bias, and the sources are often unconventional but are expected to be able to substantiate with better relevance critical arguments against the established order. Frequently, interlocutions and discursive articulations exist with subaltern popular political traditions. Political ecology has links to socioenvironmental activism at different scales.

Fifth, and finally, both Latin American critical thinking and the political ecology elaborated in the region are located on the frontier, in relation to the established knowledge systems. Despite being a co-participant to the University Reform spirit, Mariategui could be defined as "non-university and even anti-university", although he would have directed the Popular Universities Gonzalez Prada. In Brazil, inside or outside the university, the coexistence of Caio Prado Jr. or Darcy Ribeiro with academic institutionalism never was easy. In the same way, despite the remarkable momentum it has had in the region, political ecology was growing on the margins of the university structures, where, despite the appeals to interdisciplinarity, disciplinary cutbacks still resist as the basis of established structures of institutionalized power.

\section{References}

Alimonda, Héctor (comp.) 2005 Los Tormentos de la Materia (Buenos Aires: CLACSO). 
Alimonda, Héctor, Hoetmer, Raphael, Saavedra Celestino, Diego (eds.) 2009 La Amazonía Rebelde: Perú 2009 (Lima:

CLACSO/ Cooperacción/ CONACAMI/ Proyecto Democracia y Transformación Global/ Facultad de Ciencias Sociales, Universidad Nacional Mayor de San Marcos).

Alimonda, Héctor (comp.) 2011 La Naturaleza Colonizada - Ecología Politica y Minería en América Latina (Buenos Aires: CLACSO/ Ciccus).

Alimonda, Héctor 2015 "Ecologia Política Latinoamericana y Pensamiento Crítico: vanguardias arraigadas” en Desenvolvimento e Meio Ambiente (Curitiba) No 35.

Aricó, José 1982 Marx e a América Latina (Rio de Janeiro: Paz e Terra).

Aricó, José 1988 La cola del diablo - Itinerarios de Gramsci en América Latina (Buenos Aires: Siglo XXI).

Bhabha, Homi (comp.) 2010 Nación y Narración (Buenos Aires: Siglo XXI).

Biro, Andrew (ed.) 2011 Critical Ecologies (University of Toronto Press).

Boff, Leonardo 1992 América Latina, da conquista à nova evangelização (São Paulo: Ática).

Bosi, Alfredo 1992 "La vanguardia enraizada: el marxismo vivo en Mariátegui” en Anuario Mariateguiano (Lima) IV, 4.

Bryant, Raymond et al. 2012 "Bringing the other into political ecology: reflecting on preoccupations in a research field" en Singapore Journal of Tropical Geography No 33.

Comaroff, Jean, Comaroff, John 2013 Teoría desde el Sur (o como los países centrales evolucionan hacia África (Buenos Aires: Siglo XXI).

Coronil, Fernando 2008 "Elephants in the Americas? Latin American Postcolonial Studies and Global Decolonization” en Moraña, Mabel, Dussel, Enrique, Jáuregui, Carlos (eds.) Coloniality at Large (Duke University Press, Durham and London).

Cortés, Martín 2011 "Un marxismo cálido para América Latina (Apuntes para una investigación)”, en Eduardo Gruner (coord.), Nuestra América y el pensar crítico Fragmentos de Pensamiento Crítico de Latinoamérica y el Caribe (Buenos Aires: CLACSO).

Cortés, Martín 2015 Un nuevo marxismo para América Latina - José Aricó: traductor, editor, intelectual (Buenos Aires: Siglo XXI). 
de Sousa Santos, Boaventura 2006 Conocer desde el Sur - Para una cultura politica emancipatoria (Lima: Universidad Nacional Mayor de San Marcos).

de Sousa Santos, Boaventura 2010 Refundación del Estado en América Latina - Perspectivas desde una epistemología del Sur (Quito: Abya Yala).

Delgado Ramos, Gian Carlo 2013 ¿Porqué es importante la ecología política? en Nueva Sociedad, 244.

Derrida, Jacques 1994 Espectros de Marx (Rio de Janeiro: Relume Dumará).

Dussel, Enrique 2008 "Philosophy of Liberation, the Postmodern Debate and Latin American Studies” en Moraña, Mabel, Dussel, Enrique, Jáuregui, Carlos (eds.) Coloniality at Large (London: Durham Duke University Press).

Echeverría, Bolivar 2011 Discurso crítico y modernidad (Bogotá: Ediciones desde abajo).

Elizalde, Antonio 2015 “Grito de la tierra, grito de los pobres, la propuesta ética de Francisco: una recuperación de los aportes latinoamericanos a la construcción de nuestra casa común” en Desenvolvimento e Meio Ambiente (Curitiba: Universidade Federal do Paraná) No 35.

Escobar, Arturo 2005 Más allá del Tercer Mundo: Globalización y Diferencia (Bogotá: Instituto Colombiano de Antropología e Historia/ Universidad del Cauca).

Escobar, Arturo 2013 Una minga para el postdesarrollo: Lugar, medio ambiente y movimientos sociales en las transformaciones globales (Bogotá: Ediciones desde abajo).

Fals Borda, Orlando 2012 Ciencia, compromiso y cambio social (Buenos Aires: Editorial El Colectivo).

Francisco 2015 Carta encíclica Laudato Si'del Santo Padre Francisco sobre el cuidado de la casa común (Roma: Tipografia Vaticana).

Grosfoguel, Ramón 2007 "Descolonizando los universalismos occidentales: el pluriversalismo transmoderno decolonial desde Aimé Cesaire hasta los zapatistas” en Castro Gómez, Santiago y Grosfoguel, Ramón (eds.) El giro decolonial-Reflexiones para una diversidad epistémica más allá del capitalismo global (Bogotá: Siglo del Hombre Editores/ Universidad Central/ Pontificia Universidad Javeriana, Instituto Pensar).

Jameson, Fredric 2002 Pós-modernismo - A lógica cultural do capitalismo tardio (São Paulo: Ática). 
Leff, Enrique 2015 "Political Ecology: a Latin American Perspective" en Desenvolvimento e Meio Ambiente (Curitiba: Universidade Federal do Paraná) № 35.

Martín, Facundo, Larsimont, Robin 2014 "L'ecologie politique depuis l'Amerique Latine", Actes du premier colloque sur 'Penser l'ecologie politique': Sciences sociales et interdisciplinarité (Paris).

Martínez-Alier, Joan 2014 "Entre la economía ecológica y la ecología política” en Sin permiso, 16 de noviembre.

Martins, Carlos Eduardo 2006 "Pensamiento Social” en Enciclopedia Latinoamericana (São Paulo: Boitempo).

Palacio, Germán 2012 "Is there any 'Latin' in the Latin American environmental history? New challenges for the consolidation of a regional intelectual community" en HALAC I, 2.

Pratt, Mary Louise 2008 "In the Neocolony: Destiny, Destination, and the Traffic in Meaning” en Moraña, Mabel, Dussel, Enrique, Jáuregui, Carlos (eds.) Coloniality at Large (London: Durham Duke University Press).

Quijano, Aníbal 2014 Cuestiones y horizontes (Buenos Aires: CLACSO).

Roig, Arturo 2004 Teoría y crítica del pensamiento latinoamericano (México: Fondo de Cultura Económica).

Torres Rivas, Edelberto 2011 “Interrogando al Pensamiento Crítico Latinoamericano" en Cuadernos del Pensamiento Crítico Latinoamericano № 43. 